\section{Epidemiological and clinical picture of scabies in municipality of Podgorica in a Ten-year Period (2006-2015)}

\author{
Marijan Bakic ${ }^{1}$, Mirjana Bakic ${ }^{2}$, Marija Bakic ${ }^{3}$, \\ Masa Golubovic ${ }^{4}$ \\ ${ }^{1}$ The Institute of Public Health, Center for Disease Control and \\ Prevention, Podgorica, Montenegro \\ ${ }^{2}$ Clinic for Dermatovenereology KC Podgorica, Montenegro \\ ${ }^{3}$ Clinic for Dermatovenerology KC Nis, Nis, Serbia
}

\section{Abstract}

The objective of this study is to obtain data on the incidence of scabies in the city of Podgorica, the observed ten-year period (2006 to 2015) and its incidence in relation to age and gender. The second objective was to find out whether the incidence is declining to the observed period.Scabies is contagious, worldwide disease, sporadically or in epidemic form. For the creation of this parasitosis, importance is given to the socioeconomic status, living conditions, sexual promiscuity, the development of resistant populations of the parasite. In developed countries, the incidence shows a cyclical fluctuation, with long, calm intervals, while in developing countries the incidence is constantly high. The disease is spread by close physical contact, often spreading within families and it is subject to mandatory reporting. In this paper, we used the official data of the Institute for Public Health in Podgorica, which included all clinical cases reported for the ten years, a total of 1,141 people, which are classified according to age and sex, for each year. Scabies as parasitism has been reported in the highest percentage among the younger population, aged 0-20 years, more common among males. The largest number of patients is registered in 2012.

Ključne reči: epidemiology, scabies, therapy.

\section{Epidemiološka i klinička slika šuge u Opštini Podgorica u desetogodišnjem periodu (2006-2015)}

\author{
Marijan Bakić ${ }^{\text {, Mirjana Bakić }}$, Marija Bakić ${ }^{3}$, \\ Maša Golubović ${ }^{4}$ \\ ${ }^{1}$ Institut za javno zdravlje, Centar za kontrolu bolesti i \\ prevenciju, Podgorica, Crna Gora \\ ${ }^{2}$ Klinika za dermatovenerologijue, KC Podgorica, Crna Gora \\ ${ }^{3}$ Klinika za dermatovenerologijue KC Niš, Srbija
}

\section{Apstrakt}

Cilj ove studije je bio da se dobiju podaci o učestalosti šuge i njena učestalosti u odnosu na uzrast i pol u gradu Podgorici, posmatrano u desetogodišnjem periodu (2006 do 2015). Drugi cilj je bio da se utvrdi da li učestalost opada u posmatranim period. Šuga je zarazna bolest raširena na celom svetu i može se javiti sporadično ili u obliku epidemije. Za pojavu ove parazitoze značajan je socio-ekonomski status, uslovi života, seksualni promiskuitet i razvoj rezistentnih populacija parazita. U razvijenim zemljama, učestalost pokazuje ciklično kolebanje, sa dugim tihim intervalima, dok se u zemljama u razvoju učestalost je konstantno visoka. Bolest se prenosi bliskim fizičkim kontaktom, često se širi u porodici i to je podleže obaveznom prijavljivanju. U ovo članku koristili smo zvanične podatke Zavoda za Javno zdravlje u Podgorici, koja je uključivala sve kliničke slučajeva prijavljene za deset godina, ukupno 1.141 ljudi, koji su klasifikovani prema starosti i polu, za svaku godinu. Šuga kao je prijavljena u najvećem procentu među mlađom populacijom, uzrasta 0-20 godina, češće kod muškaraca. Najveći broj pacijenata je registrovan 2012. godine.

Key words: epidemiologija, svrab, terapija.

Scabies (itch) is a common, parasitic and extremely pruritic dermatoses, caused by a mite Sarcoptes scabiei var. hominis, which belongs to the genus Sarcoptes the family Sarcoptidae. The mite is an obligate, octopodid parasite, length 0.4 and width $0.3 \mathrm{~mm}$. Copulation occurs in small tunnels that female digs in the skin, or the skin's surface, which lays an average of three eggs a day. Mites die in ten minutes at 50 degrees, at room temperature out of human skin can survive from one to four, and according to some authors up to five days $^{1}$. The frequency of this parasitic disease in the world is estimated at about 300 million cases per year. Scabies occurs in both sexes and at all ages, in all ethnic groups and all socioeconomic level ${ }^{2}$. Although is no generally accepted, the opinion is that case of scabies it is often present in people of lower socioeconomic 
status. In developed countries, a quiet interval between the two decades of the epidemic indicates distance (10-15 yr.), While in developing countries the incidence is still high. Although the prevalence of scabies in the world shows the cyclical fluctuations, not all parts of the world are in at the same stage of the cycle. In Europe and North America, in 1960, there was a significant increase in prevalence, but by 1980 it reached almost pandemic levels ${ }^{3}$. The incidence of scabies in the population is increased when more people is present in one place, therefore outbreaks may occur in an institutional setting. Compared to the season, the itch is more common in winter than in summer, possibly due to increased physical overcrowding in winter and dust mites can survive longer at low temperatures ${ }^{4}$.

The predominant route of transmission is direct physical contact (sleeping in the same bed, handling), causing transfer between family members and in closed collectives, communities. Due to the potential transmission through sex, scabies is listed as one of the sexually transmitted diseases. Incubation with the first infection is 3 to 4 weeks, a full-blown clinical picture occurs after two months. Incubation with the reinfection (secon infection) is shorter, due to the already developed allergic sensitization, and is only 2-3 days. The first and dominant subjective symptom is itching, whose intensity correlated with the activity of the mites, why patients report itching of the second half of the night, when is the extensive mite activity ${ }^{5}$. In the clinical picture of uncomplicated scabies dominate papules with a typical distribution on the interdigital folds, flexor surfaces of wrists, foreskin(preputium) in men. In the elderly, the changes are also on the skin of the abdomen, while the infant pruritic papules found on the palms and soles, which has an important differential diagnostic significance. In some cases there is Gorchakov- Hardy symptom presented with papulovesicular excoriation and crust cover, with symmetrical distribution in the mentioned regions, as well as perimamilarno in women, at the front armpit crease, periumbilikalno, lower abdomen, gluteal region, thighs. This is the most common clinical picture in everyday practice. Crusted („Norwegian“) scabies occurs to a disturbed immune response of the host, allowing the parasite to multiply and reach the number of several million. Nodular and bullous scabies is more common in infants and young children and is probably a consequence of hypersensitivity to agents. When it occurs in the elderly, can mimic bullous pemphigoid, and may causes delay of the diagnosis. Scabies on the scalp develops in infants and immunocompromised hosts and can mimic seborrheic dermatitis. Scabies incognito is a widespread form that occurs due to use of local corticosteroids application .

The diagnosis is simple in case of uncomplicated scabies, with a typical distribution of papules and severe nightly itching. However, an atypical form may represent the diagnostic problem, as well as the clinical picture which is changed with irritation, ekzematisation, local corticosteroid therapy. It is particularly difficult to diagnose people who regularly and meticulously maintain hygiene, but after the applied therapy (ex juvantibus), we find out the possible etiology of itching. The diagnosis can be correctly made only if mites, or their parts, or eggs, are founded on a microscope slide, and more recently, using dermoscopy, which is a leading diagnosis method of this parasitosis in Europe ${ }^{6}$. The therapeutic modality is depending on the countries where the infection is occured, but mostly it is topical medications. In our country the longest use has a sulfur concentration of $5-15 \%$ typically with vaseline, three days, in the evening, except for the face and scalp, a fourth day is followed by bathing and changing clothes and bedding. It can be used in children younger than two years, and in pregnant women. Other topical treatments are: $25 \%$ benzyl benzoate (not available in the United States), can be applied once in $24 \mathrm{~h}$, Krotamiton 10\%, 1\% lindane as a lotion. However, the potential neurotoxicity of lindane, particularly in repeated applications, greatly limits its use ${ }^{7}$ product is no longer available in the UK or Australia. Locally applied 5\% Permethrin shows akaricid and ovocidan effect, there is a minimum mite resistance, side effects are rare and can be used in children, pregnant women, nursing mothers. It is applied for 8-14 hours, and the treatment is repeated after eight days ${ }^{8}$. The Center for Disease Control and Prevention (CDC), recommends permethrin as a first-line therapy 9 . In case of resistance to topical medications, in severe form, and in cases of form called „Norwegian scabies" the drug of choice is oral Ivermectin given at a dose of 200 micrograms per kilogram, Ivermectin should be a routine therapy for patients who do not respond to locally applied scabicides, and this may be the first choice of treatment in elderly patients with generalized eczema. It is contraindicated in children younger than five years old, weighing less than $15 \mathrm{~kg}$, pregnant women and nursing mothers. A second dose of ivermectin after two weeks increased the cure rate to 95 percent $^{10}$. Patients should be told that the itching can last up to four

MATERIA MEDICA • Vol. 32・No. 3 • decembar 2016. 
weeks after completion of adequately implemented therapy. After this period, the cause of itching should be reexamined. When it comes to control of efectivity infectivity after treatment, the time line for the elimination of parasites after treatment for classic scabies has not been studied in detail. However, the recovery of live mites from chairs and couches in the homes of patients with scabies supports the use of environmental measures ${ }^{11}$. Clothing and bedding which had been in contact with the patient during the previous 48 to 72 hours should be machine-washed at $60^{\circ} \mathrm{C}^{12}$. A sensitive and specific method of scabies diagnosis is still not found.

The aim of this study was to obtain data on the incidence of scabies to me in the city of Podgorica in the observed ten-year period (2006-2015), as well as the age and sex frequency. Another objective was to find out whether the incidence is declining in the period.

\section{Materials and Methods}

This paper uses data of the Institute for Public Health in Podgorica, gained after reporting any patient with symptoms resembling scabies to me, and after clinical and diagnostic confirmation of the Department of Dermatology in Podgorica. The study included a total of 1141 patients, of which men's 578 (50.66\%), females 563 (49.34\%) on the territory of Podgorica in the period from 2006 to 2015.

\section{Results}

The incidence of scabies in an area of Podgorica, over the ten-year period (2006-2015), Graphicon 1. shows significant low incidence recorded in the period 2006-2011 year.

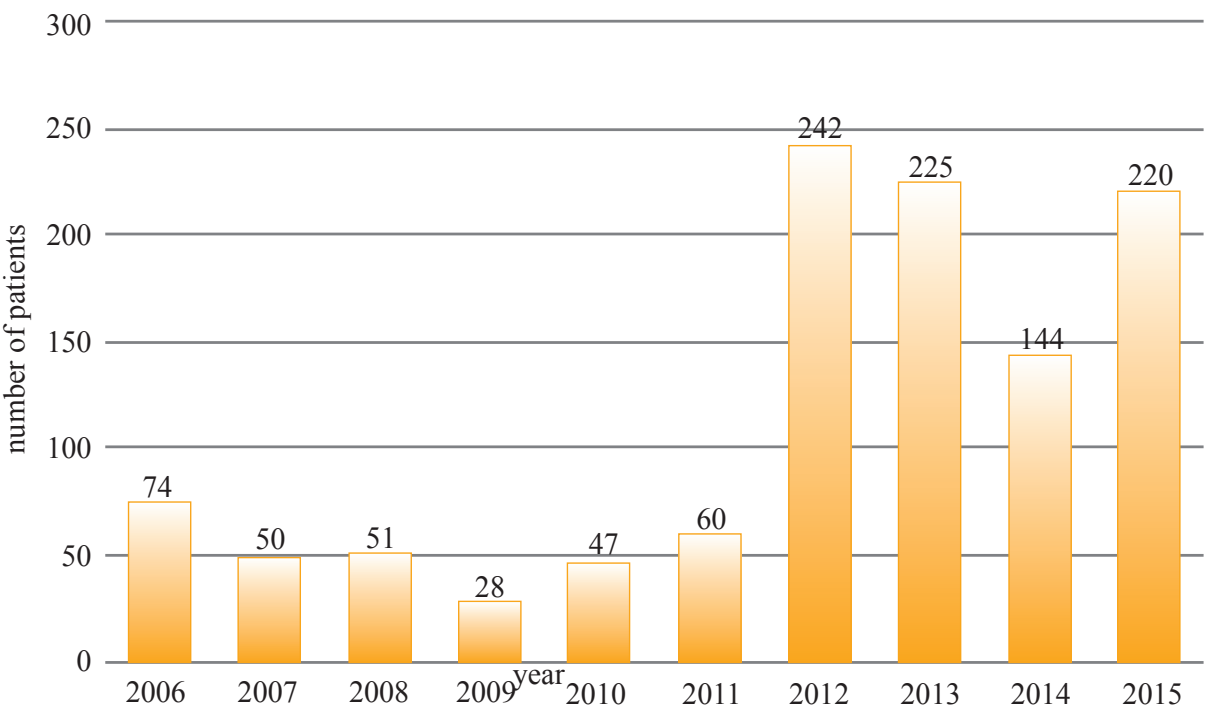

Graphicon 1. Incidence of scabies in the Podgorica area duringthe 2006 -2015.

In the seventh year (2012 year), there was a sudden increase in infected scabies who is eight and a half times higher than in the previous year, or in 2009, when it registered the lowest number of patients in the observed decade. The number of patients treated was 1141, of which 578 men and women 563 (Table 1.). 


\section{ORIGINALNI RADOVI}

\begin{tabular}{|l|l|l|l|}
\hline $\begin{array}{l}\text { Godine } \\
\text { Year }\end{array}$ & $\begin{array}{l}\text { Muškarci } \\
\text { Males }\end{array}$ & $\begin{array}{l}\text { Žene } \\
\text { Females }\end{array}$ & $\begin{array}{l}\text { Ukupno } \\
\text { Total }\end{array}$ \\
\hline 2006 & 38 & 36 & 74 \\
\hline 2007 & 27 & 23 & 50 \\
\hline 2008 & 27 & 24 & 51 \\
\hline 2009 & 13 & 15 & 28 \\
\hline 2010 & 21 & 26 & 47 \\
\hline 2011 & 33 & 27 & 60 \\
\hline 2012 & 130 & 112 & 242 \\
\hline 2013 & 103 & 122 & 225 \\
\hline 2014 & 75 & 69 & 144 \\
\hline 2015 & 111 & 109 & 220 \\
\hline $\begin{array}{l}\text { Ukupno } \\
\text { Total }\end{array}$ & $\mathbf{5 7 8}$ & 563 & 1141 \\
\hline $\begin{array}{l}\text { Ukupno } \\
\text { Total (\%) }\end{array}$ & $\mathbf{5 0 , 8 \%}$ & $\mathbf{4 9 , 1 3 \%}$ & \\
\hline
\end{tabular}

Table 1. The number of scabies cases during the 2006-2015 period in the Podgorica area according to sex.

The frequency of scabies by age groups, is shown in Graphicon 2.

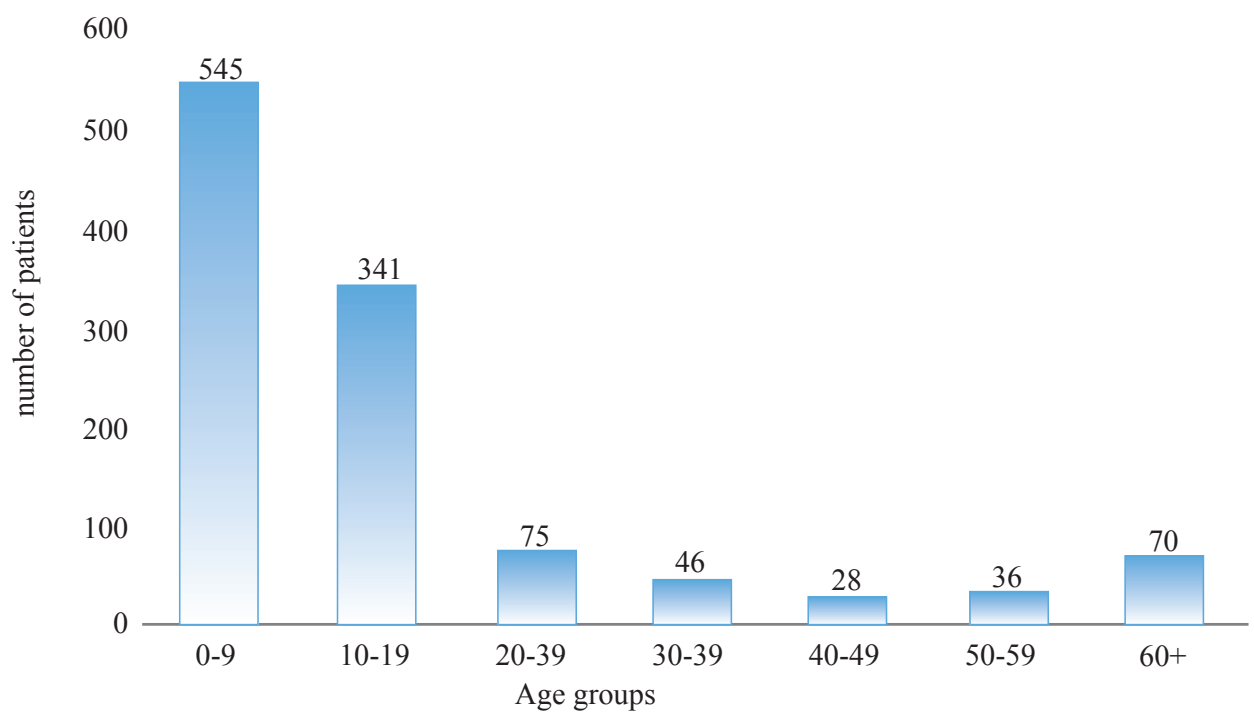

Graphicon 2. The incidence of scabies duringthe 2006-2015 period in the Podgorica area according to age.

Two age groups show a significant deviation, the age group 0-9 years (545 patients, or 48\%), which recorded the highest number of patients, and those 10-19 years of age (341 patients, or 30\%), accounting for a total of $78 \%$ of all patients, while patients in other age groups are markedly less frequent, only $22 \%$. The age group of 0-9 years is ahead in all years except in 2010 when it registered a higher number of patients in the age group 10-19 years. In the first three decades of life (0-29 years old) percentage of patients with scabies is $85 \%$. Thus, three-quarters of our patients are young people from the age of 30 , while the other 4 decades accounts for only $15 \%$ Graphicon 3. 


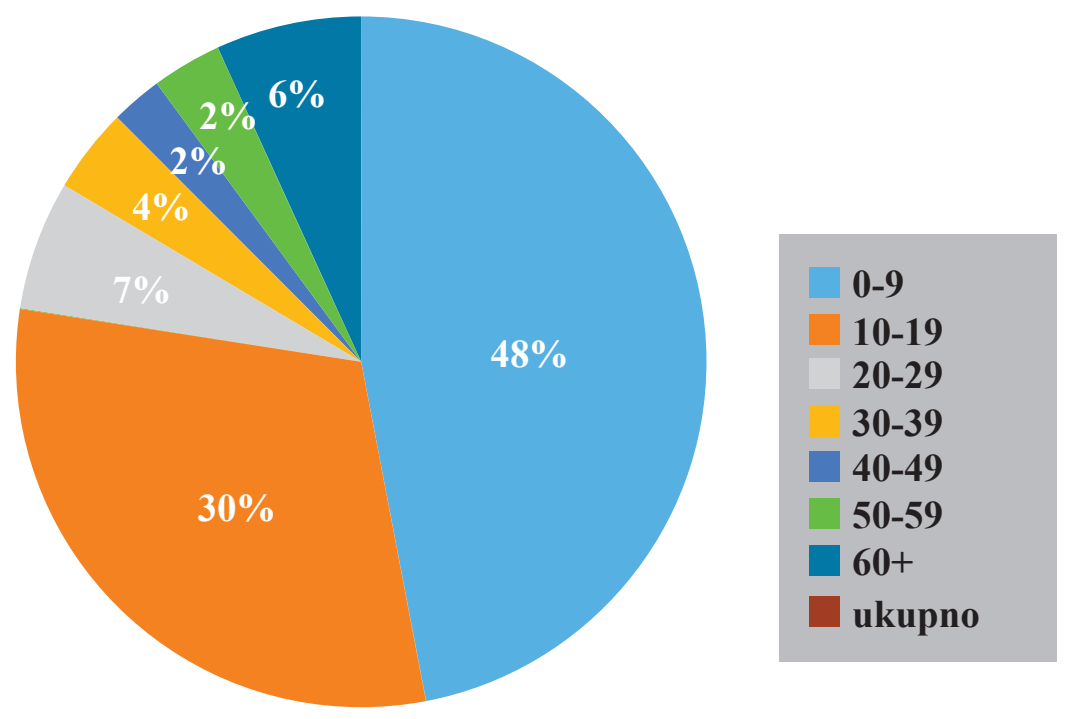

Graphicon 3. The number of scabies cases duringthe 2006-2015 period in the Podgorica area according to age.

The incidence of scabies cases by sex is shown in Graphicon 4. The man (50.66\%) and women (49.34\%).

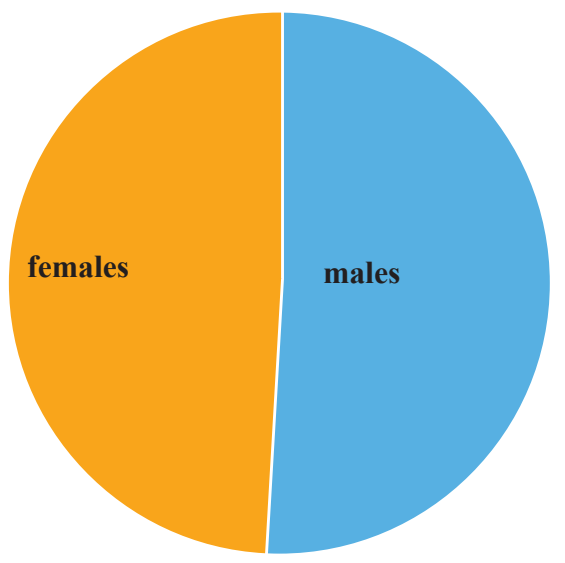

Graphicon 4. The number of scabies cases duringthe 2006-2015 period in the Podgorica area according to sex.

\section{Discussion}

Scabies is a global medical and dermatological problem, which shows the cyclicality of reporting in the developed countries, example is Denmark, which records the long, quiet intervals of 15-27 years. In developing countries, the certain incidence of scabies still present. In our data, there is increase in the incidence of scabies in two age groups (0-9 and 10-19 years of age), correlating with researches of other authors who have similar foundings. This age group of up to 30 years account for more than three-quarters of patients in the territory of Podgorica. International Federation for control of scabies(IACS) was founded 
in 2012 with the aim to present information on the current epidemiological situation throughout the world, as well as to draw attention to the fact it may occur more complications in terms pyodermas, streptococcal infections, glomerulonephritis. Certain categories of people are considered to be vulnerable to the emergence of parasites such as children, young, sexually active people, the elderly, immunocompromised, as well as individuals in tropical and poor areas. Changes on skin are the consequences of hypersensitivity reactions to dust mites ${ }^{11}$. The predominant route of transmission is direct contact. It occurs also sexual transmission. In a study that assessed the factors of high risk for scabies at the Clinic for Venereology ${ }^{12}$, were included men who had same-sex relationships and men with sporadic sexual contacts. There is no evidence to suggest that mites can transmit the infection of human immunodeficiency virus. The epidemiological study in the UK, has shown that scabies is more common in urban areas and among women and children, and more often in winter than in summer ${ }^{13}$. In the developed world, in the UK, the mean frequency for a period of nine years (1997-2005),ranged from 2.81 for women and men 2.27 per $1000^{14}$. In Podgorica is recorded a slightly higher number of infected males compared to female, 1: 1,026. Epidemiological data from Geneva indicated a significant increase in the diagnosis of new cases of scabies in October $2011^{15}$. In Greece, the itch continues to be a significant problem especially among immigrants, re- ing for $4.8 \%$ of diagnoses made, and it had changed little between cohorts over 30 years compared ${ }^{16}$. At the dermatology clinic in Spain, it was found that immigrants make up $4.1 \%$ of dermatological patients and that scabies(together with other infectious dermatoses) more common in this group in comparison to the members of the local indigenous population ${ }^{17}$, data has shown from the Palestinian territories indicate the average annual incidence of scabies on 17/100 000 from 2005 to 2010. Significantly higher in children below 10 years of age and the elderly, so that mandatory reporting of cases as a way of increasing awareness in terms of better prevention and control strategies ${ }^{18}$. In poor areas of the world, scabies is one of the most common dermatological and health problems. A recent study from North India ${ }^{19}$, has shown the prevalence of scabies $4.4 \%$; Chile reported prevalence of scabies is $1-5 \%{ }^{20}$. Social issues and overpopulation is considered to contribute to the risk of developing of scabies. This is confirmed by studies of primary health facilities in areas affected by the earthquake, so it is in Pakistan itch immediately after viral infection of the upper respiratory tract 17 versus $23 \%{ }^{21}$.

\section{Conclusion}

Based on recorded data in municipality of Podgorica, there has been no incidence increase in the past four years. Scabies is most common between ages 0 to 9 and from 10 to 19 years, making $78 \%$ of all patients in the city of Podgorica. The incidence of males (50.87\%) and women (49.13\%) sex ratio is 1: 1,035. Scabies is contagious but benign dermatoses. The predominant route of transmission is direct close contact, including sexual transmission. Ignoring the diagnosis of scabies have additional health and economic implications, particularly in the context of the epidemic. Further progress in this area would be significantly improved diagnostics, as well as sensitive, specific and inexpensive diagnostic test. The most important measures are prevention and adequate therapy treatment.

\section{Literatura}

1. Wilson CD, Leyva HW, King EL. Arthropod bites and sting In: Fitzpatrick TB, Eisen AZ, Wolff K, Freedberg IM, Austen FK. Dermatology in general medicine NewYork: McGraw-Hill, 1993:2810-26.

2. Downs AMR, Harvey I, Kennedy CTC. The epidemiology of head lice and scabies in the UK. EpidemiolInfect 1999;122:471-477.

3. Romani L, Steer AC, Whitfeld MJ, Kaldor JM. Prevalence of scabies and impetigo world wide: a systematicreview. Lancet Infect Dis 2015; 15:960.].

4. Chosidow O. Clinical practices. Scabies. N Engl J Med 2006; 354:1718.

5. Simić Č, Živković V, editori. Familija Sarcoptidae. U Artropodi-paraziti čoveka i domaćih životinja. Beograd: Medicinska knjiga; 1958.28-54.

6. Argenziano G, Fabbrocini G, Delfino M. Epiluminescencemicroscopy. A newapproach to in vivodetectionofSarcoptesscabiei. ArchDermatol .1997; 133: 751-3

MATERIA MEDICA • Vol. 32 • No. 3 • decembar 2016. 
7. Bhalla M, Thami GP. Reversible neurotoxicity after anoverdose of topicallindane in an infant. PediatrDermatol 2004;21:597-599.

8. Quartermnan MJ, Lesher JL. Neonatal scabies treated with permetrin 5\% cream. Pediatr Dermatol 1994; 11: 264-6.

9. Scabiesfactsheet. Atlanta: Centers for Disease Control and Prevention, 2005.

10. Usha V, Gopalakrishnan Nair TV. A comparative study of oral ivermectin and topical permethrin cream in thetratment of scabies. J Am AcadDermatol 2000; 42:236.

11. Arlian LG, Estes SA, Vyszenski-Moher DL. Prevalence of Sarcoptes scabiei in the homes and nursing homes of scabietic patients. J Am Acad Dermatol 1988;19:806-811

12. Elston DM. Controversies Concerning The Treatment Of lice andscabies. J Am Acad Dermatol 2002;46:794-796

13. Arlian LG, Runyan RA, Achar S, Estes SA. Survival and infectivity of sarcoptes scabiei var. canis and var. hominis J Am Acad Dermatol 1984;11:210-215

14. Otero L, Varela JA, Espinosa E, et al. Sarcoptes scabiei in a sexually transmitted infection sunit: a 15-year study. Sex Transm Dis 2004;31:761-765

15. Downs AMR, Harvey I, Kennedy CTC. The epidemiology of head lice and scabies in the UK. Epidemiol Infect $1999 ; 122: 471-477$

16. Lassa S, Campbell MJ, Bennett CE. Epidemiology of scabies prevalence in the U.K. from general practice records. Br AssocDermatol 2011; 164:1329- 1334.

17. Gaspard L, Laffitte E, Michaud M, et al. Scabies 2012. Rev Med Suisse 2012; 8:718-722; 724-725.

18. Katsarou A, Armenaka M, Kosmadaki M, et al. Skin diseases in Greek and immigrant children in Athens. Int J Dermatol 2012; 51:173-177.

19. Albares MP, Belincho'n I, Ramos JM, et al. Epidemiologic study of skin disease samong immigrants in Alicante, Spain. Actas Dermosifiliogr 2012; 103:214-222

20. Amro A, Hamarsheh O. Epidemiology of scabies in theWest Bank, Palestinian\&Territories (Occupied). Int J Infect Dis 2012; 16:e117-e120.

21. 1 Grills N, Grills C, Spelman T, et al. Prevalence survey of dermatological conditions in mountainous north India. Int J Dermatol 2012; 51:579-587.

22. Moreno MC. Ectoparasitosis of clinical importance in Chile. Rev ChilenaInfectol 2011; 28:435-439.

23. Shah N, Abro MA, Abro MA, et al. Disease Pattern in earthquake affected areas of Pakistan: data from Kaghan valley. J Ayub Med Coll Abbottabad 2010;22:81-86.

Autor za korespondenciju:

Dr Marijan Bakić specialist of epidemiology

Dzona Dzeksona Podgorica e-mail: marijan.bakic@ijzcg.me 